\section{Long-lasting Remission of Severe Behçet's Disease After the End of Infliximab Therapy}

\section{To the Editor:}

In the May 2008 issue of The Journal we described the case of an Italian Olympic athlete with Behçet's disease (BD) who had a long-lasting remission after treatment with infliximab ${ }^{1}$, enabling him to take part in international athletic competitions. To date, the duration of the complete remission is 3.5 years. In the last 12 months, the dose of infliximab has been 3 $\mathrm{mg} / \mathrm{kg}$ and the interval between the infusions 3 months. Previously, the drug was given at a dose of $5 \mathrm{mg} / \mathrm{kg}$ every 2 months. Azathioprine has always been taken at the low dose of $0.7 \mathrm{mg} / \mathrm{kg} / \mathrm{day}$ with the intention of reducing the immunogenicity of infliximab. The ability to maintain complete remission of $\mathrm{BD}$ with a very low dosage of infliximab could have permitted us to interrupt the therapy. We decided to continue since the athlete is still active and wants to compete for 2 more years.

We are following another patient with BD who had a long-lasting remission after the end of infliximab therapy. The patient, a 24-year-old man, came to the outpatient clinic of the Rheumatology Department of Lucania in November 2001. The disease had started 6 months before, with posterior uveitis of the left eye. Subsequently, recurrent oral apthosis, bilateral anterior uveitis, papulopustolosis, and erythema nodosum had appeared. His history and family history were unremarkable. Examination showed oral apthae and skin papulopustular lesions. Ophthalmological evaluation revealed acute anterior uveitis in both eyes and corioretinitis in the left. HLA typing was positive for B51 antigen.

He was given cyclosporine $3 \mathrm{mg} / \mathrm{kg} / \mathrm{day}$ and prednisone $25 \mathrm{mg} / \mathrm{day}$. In the following months there was partial improvement of the eye and mucocutaneous symptoms and signs. The prednisone dose was progressively tapered to $4 \mathrm{mg} /$ day. In May the dose of cyclosporine was reduced to 2.5 $\mathrm{mg}$ /day due to a mild increase of serum creatinine.

In September 2002, the posterior uveitis of the left eye was worse despite cyclosporine therapy. With the patient's consent we stopped cyclosporine and began intravenous infliximab therapy $5 \mathrm{mg} / \mathrm{kg}$ at Weeks 0,2 , and 6 and subsequently every 2 months. There was rapid improvement of the eye symptoms and signs until they disappeared after the third infusion. The mucocutaneous lesions disappeared and have not reappeared.

The patient withdrew his consent to infliximab therapy in December 2004 after the 13th infusion. He had been without any symptoms and signs of the disease for 2 years and did not want to continue treatment. Since then, we have examined him twice a year. The disease has remained in complete remission to date.

This patient has had a very long remission with infliximab therapy, a duration of 6 years of which 2 taking infliximab therapy and 4 without any drug. Unlike the athlete, the complete remission has persisted after the end of infliximab therapy. It is notable that both patients are young men at increased risk of developing systemic complications, which carry significant morbidity and mortality ${ }^{2,3}$.

Our present case suggests that the remission obtained with infliximab can persist for a long time after the end of therapy. A question arises: can patients with BD treated early with infliximab, as with our 2 cases, recover from the disease? The answer will come from studies on large numbers of patients and continuous followup of our 2 patients.

IGNAZIO OLIVIERI, MD, Consultant, Director; ANGELA PADULA, MD, Researcher; PIETRO LECCESE, MD, Research Fellow; SALVATORE D'ANGELO, MD, Researcher; VINCENZO GIASI, MD, Researcher, Rheumatology Department of Lucania, San Carlo Hospital of Potenza and Madonna delle Grazie Hospital of Matera, Potenza and Matera, Italy. Address reprint requests to Dr. I. Olivieri, Rheumatology Department of Lucania, Ospedale S. Carlo, Contrada Macchia Romana, 85100 Potenza, Italy. E-mail: ignazioolivieri@tiscalinet.it

\section{REFERENCES}

1. Olivieri I, Latanza L, Siringo S, Peruz G, Di Iorio V. Successful treatment of severe Behçet's disease with infliximab in an Italian Olympic athlete. J Rheumatol 2008;35:930-2.

2. Kural-Seyahi E, Fresko I, Seyahi N, et al. The long-term mortality and morbidity of Behçet's syndrome: a 2-decade outcome survey of 387 patients followed at a dedicated center. Medicine Baltimore 2003;82:60-76.

3. Tugal-Tutkun I, Onal S, Altan-Yaycioglu R, Huseyin Altunbas H, Urgancioglu M. Uveitis in Behçet's disease: an analysis of 880 patients. Am J Ophthalmol 2004;138:373-80.

J Rheumatol 2009;36:4; doi:10.3899/jrheum.081063 